\title{
DIE STAND VAN KLINIESE EVALUERING AAN SUIDER-AFRIKAANSE UNIVERSITEITE
}

\section{Magda Mulder en Marlene Viljoen}

\section{Summary}

The fact that clinical evaluation is a difficult and complex task of nursing education has been emphasized in the nursing literature since the early seventies. It is, neverthcless, a most important component of the teaching-learning process of nursing saudents and it has definite advantages. It:

* contributes to the improvement of the standard of nursing care

* helps to identify problem areas for research and

* contributes to high level professional preparation.

In the light of these factors the aims of the study were to:

* determine and describe the position of clinical evaluation as a component of the teaching of undergraduate students in departments of nursing at universities in Southern Africa;

* draw up a proto-theoretical model for clinical evaluation.

The second aim will be fully discussed in a follow-up article.

The empirical data showed that nursing educationists in Southern Africa are not cntirely up to standard regarding the skills required for clinical evaluation.

\section{Opsomming}

Reeds vanaf die vroeë sewentigerjare tot vandag, word daar in die verpleegliteratuur daarop gewys dat kliniese evaluering 'n moeilike en 'n komplekse taak van verpleegonderwys is.

Kliniese evaluering is egter 'n uiters belangrike komponent van die onderrig-leerproses van studentverpleegkundiges en dit hou definitiewe voordele in. Dit:

* lewer 'n bydrae tot die verhoging van die standaard van verpleegsorg;

* help met die identifisering van probleemareas vir navorsing; en

* lewer 'n bydrae tot hoëvlakberoepswoorbereiding.

In die lig van bogenoemde was die doelstellings van die studie om:

* die stand van kliniese evaluering as onderrigkomponent van voorgraadse studente van Departemente van Verpleegkunde aan Suider-Afrikaanse universiteite te bepaal, en te beskryf;

* 'n proto-teoretiese model vir kliniese evaluering op te stel.

Die weede doelstelling word volledig in 'n opvolgartikel bespreek.

\section{INLEIDING}

Voltooing van professionele opleiding word nic deur alle werkgewers as 'n bewys van suksesvolle kliniese praktykopleiding van verplecgkundiges beskou nie. Hierdie onsekcrheid word dikwels bevestig wanneer werkgewers vind dat pas gegradueerdes of gediplomeerdes nie oor die nodige kliniese vaardighede beskik nie. Opvoedkundiges daarentecn, ervaar dat die opstel van kwalitatiewe evalueringsinstrumente 'n komplekse taak is en dat kliniese evaluering op sigself subjektief van aard is. Studente ervaar hoc spanningsvlakke tydens evaluering en is van mening dat dit nie betroubaar en regverdig geskied nic.

In die lig van hierdic en soortgelyke aangelecnthede, is opvoedkundiges en werkgewers toenemend daarvan nortuig dat die resultate van die opvoedkundige ondervinding 'n tasbare bewys moet wees dat leer wel plaasgevind het en dat dit volgens 'n sistematiese en objektiewe wyse gemeet is. Daarom dat verpleegopvoedkundiges, en opvoedkundiges op verskeic ander studieterreine al hoe meer hul andag op die spesilicke vaardighede wat gemeet moet word en die evaluasiemetodes, en-tegnieke fokus.

Dit blyk ook duidelik uit die literatuur (Lenburg, 1978:259) dat sodra alle onduidelikheid met betrekking tor die verwagte bevoegdhede uit die weg geruim is en die evalueringstrategieè noukeurig beplan is, kliniese evaluering 'n lecrondervinding word waanydens die student groei en ontwikkel.

Dàr word egter deurgaans vanaf die vroeë sewentigerjare tot vandag, in die verplecgliteratuur daarop gewys dat kliniese evaluering 'n mocilike en komplekse taak van verpleegonderrig is (Litwack, Sakata \& Wykle, 1972:141; Morgan \& Irby, 1978:xi; Sachs, 1980:63; Loustou et al. 1980:10, Guilbert, 1981:212; Sweeney, Hedstrom \& O'Malley, 1982a:5; Wood, 1982:11 en 12; Kolb \& Shugart, 1984:84). 
Verskeie opvoedkundiges het hulle dan ook sterk oor die aangelcentheid uitgespreek onder andere:

Evaluation of student clinical performance has created headaches for nursing educators for decades (Sommerfeld \& Accola, 1978:432).

The evaluation of educational outcomes remains one of the stubborn problems facing education today (Lynch, 1974:1).

Clinical evaluation has long been accorded considerable importance by nurse educators, but has presented chronic frustrations for our profession (Abbot et al. 1988:219).

Vir ' $n$ ander opvoedkundige is evaluering weer 'n "...mysterious area of nursing education" (Woolley, 1977:308).

Kliniese evaluering is egter 'n uiters belangrike komponent van die onderrig-leerproses van studentverplecgkundiges en dit hou definitiewe voordele in. Dit:

- lewer 'n bydrae tot die verhoging van die standaard van verpleegsorg;

- help met die identifisering van problecmareas vir navorsing; en

- lewer 'n bydrae tot hoëvlakbcroepsvoorbereiding.

\section{KEUSE VAN \\ NAVORSINGSONDERWERP}

Jarclange worsteling met die problematiek van kliniese evaluering in Verpleegkunde en 'n bewuswording van die belangrikheid van hierdie aspek van dic kliniese onderrigproses, het die navorser oorreed om 'n intensiewe studie te doen na die stand van kliniese evaluering in Verpleegkunde

\section{DOELSTELLINGS VAN DIE STUDIE}

Die doelstellings van die studie was om:

a) die stand van kliniese evaluering as onderrigkompomponent van voorgraadse studente van Departemente van Verplecgkunde aan Suider-Afrikaanse ${ }^{1}$ universiteite $^{2}$ tc bepaal, $\mathrm{cn}$ te beskryf.

b) Om 'n model vir kliniese evaluering te konstrueer.

Die eerste doelstelling is in die volgende doelwitte uitgebou. Daar is gepong om vas te ste!:

- wat die professionele agtergrond van kliniese evalucerders is
* wat die respondente se siening en mening met betrekking tot kliniese evaluering is

- watter probleme met kliniese evaluering ondervind word en watter oplossings in die verband aanbeveel word

* hoe kliniese evaluering beplan word

- volgens watter wyse kliniese evalueringsinstrumente opgestel en getoets word

- volgens watter wyse word kliniese evaluering geïmplementeer.

Weens die omvang van die studie word slegs die belangrikste resultate van die eerste drie doelwitte in hierdie artikel bespreek. Die tweede hoofdoelstelling, naamlik 'n voorgestelde model vir kliniese evaluering word in 'n opvolgartikel behandel.

\section{DIE AANNAMES VAN DIE NAVORSING}

\section{Aanname 1}

Kliniese evaluering is deel van die onderrigkomponent van voorgraadse studentverpleegkundiges wat 'n geïntegreerde graadkursus in Verpleegkunde aan Suider-Afrikaanse universiteite volg.

\section{Aanname 2}

Genoemde Departemente van Verpleegkunde se onderrigdoelstellings en doelwitte is in ooreenstemming met dic programdoelstellings soos voorgeskryf deur die betrokke professionele statutêre liggame.

\section{Aanname 3}

Die vraelyste van die studie is eerlik, objektief en sonder vooroordeel voltooi.

\section{Aanname 4}

Die kliniese evalueerder se professionele opleiding en ervaring stel haar in staat om haar mening oor verskeie aspekte van kliniese evaluering uit te spreek, en haar mening word in gevalle waar geen ander aanduiding van die veranderlike beskikbaar is nie, as'n aanduiding van die veranderlike beskou.

\section{METODOLOGIE EN ONTWERP VAN DIE STUDIE}

'n Beskrywende studie in die vorm van 'n opname is binne die raamwerk van ' $n$ nie eksperimentcle navorsingsontwerp gedoen.

'n Intensiewe litcratuurstudie met kliniese evaluering as hooftema het as verwysingsraamwerk vir die empiriese studie gedien en later ook vir die samestelling van die model vir kliniese cvaluering.

\section{POPULASIE}

Dic studie sluit alle Departemente van Verpleegkunde ( $N=16)$ aan Suider-Afrikaanse universiteite in. Slegs personeel wat aktief by die kliniese evaluering van voorgraadse studente in algemene verpleegkunde, psigiatriese verpleegkunde, verloskunde en gemeenskapsverplecgkunde betrokke was, is by die studie betrek.

\section{NAVORSINGSINSTRUMENT}

Gesiruktureerde posvraelyste was geskik as dataversamelingstegniek omdat dit in terme van geld en tyd koste-effektief is en omdat die aard van data wat versamel is, nie indringende onderhoudvocring sou verg nie.

Data met betrekking tot die organisering van kliniese evaluering is slegs by die hoofde (of verantwoordelike persoon) van elke afdeling van verpleegkunde ingesamel om sodoende onnodige duplisering van data uit te skakel.

Meer persoonlike en opiniegerigte inligting (sienings, probleme, aanbevelings, aktiwiteite rondom kliniese evaluering, sosiobiografiese data en so meer) is van alle respondente verkry.

Twce vraelyste is dus gebruik: Vraelys I vir afdelingshoofde of verantwoordelike persone en Vraclys II vir die res van die personeel wat aktief by kliniese evaluering betrokke is.

Dic navorser het die volgende stappe geimplementeer om aan die eise van inhoudsen gesigsgeldigheid te voldoen:

- Aanvanklik is navorsingsdoelwitte en temas, met die literatuurstudie as verwysingsraamwerk, geidentifiseer.

- Daarna is voldoende vrae opgestel om die doelwitte te beantwoord.

- Om onduidelikheid uit te skakel het elke respondent 'n Afrikaanse en Engelse vraelys ontvang.

- Konsepte wat moontlik onbekend of verwarrend mag wees is omskryf en saam met die vraelys uitgestuur.

* Die vraelyste is deur sewe deskundiges (meesal senior verpleegopvoedkundiges met etlike jare verpleegpraktyk- en verpleegondenwyservaring) bcoordcel.

* Dic vraclyste is daarna in 'n loodsstudic op 'n groep verpleegopvoedkundiges

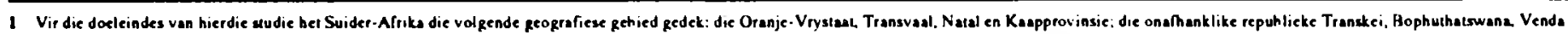

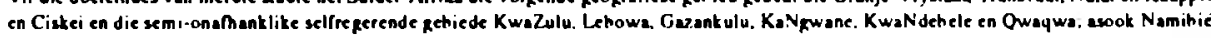

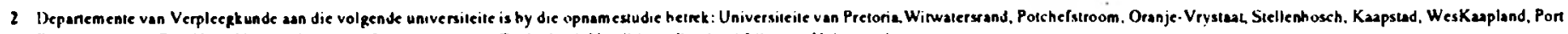
Elizaheih. Natal, Fon Hare. Noorde. Medunse. Hoghuthalswana Zoelocland. Namihie en Kandse Arritaanse Universiteit.

3 Vier afdelingshoofde en apl tliniese dosenie ( $N=1$ 2) van 'n Bloem fonieinse Verpleegopleidingakollege is vir die londsstudie gehruik. 
Figuur 1

Graflese Voorsetlling van die hoogste akademlese kwallfikasie in verpleegkunde van die respondente $(n=103)$

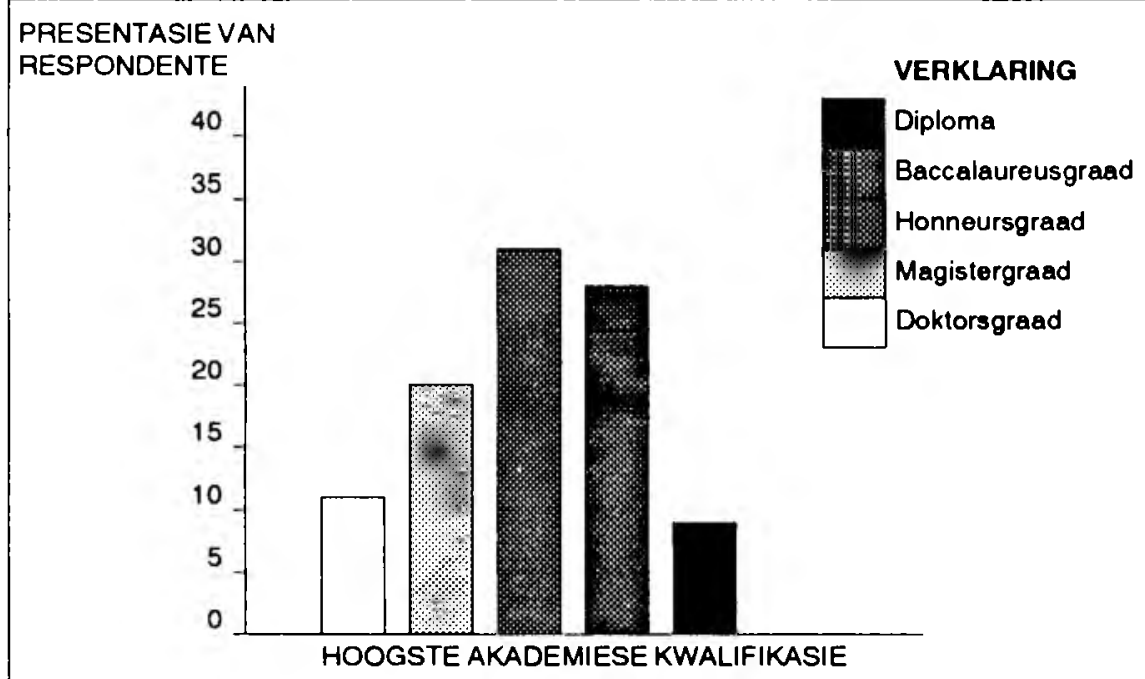

Figuur 2

Professionele Reglstrasies van die respondente $(\mathrm{N}=104)^{1}$

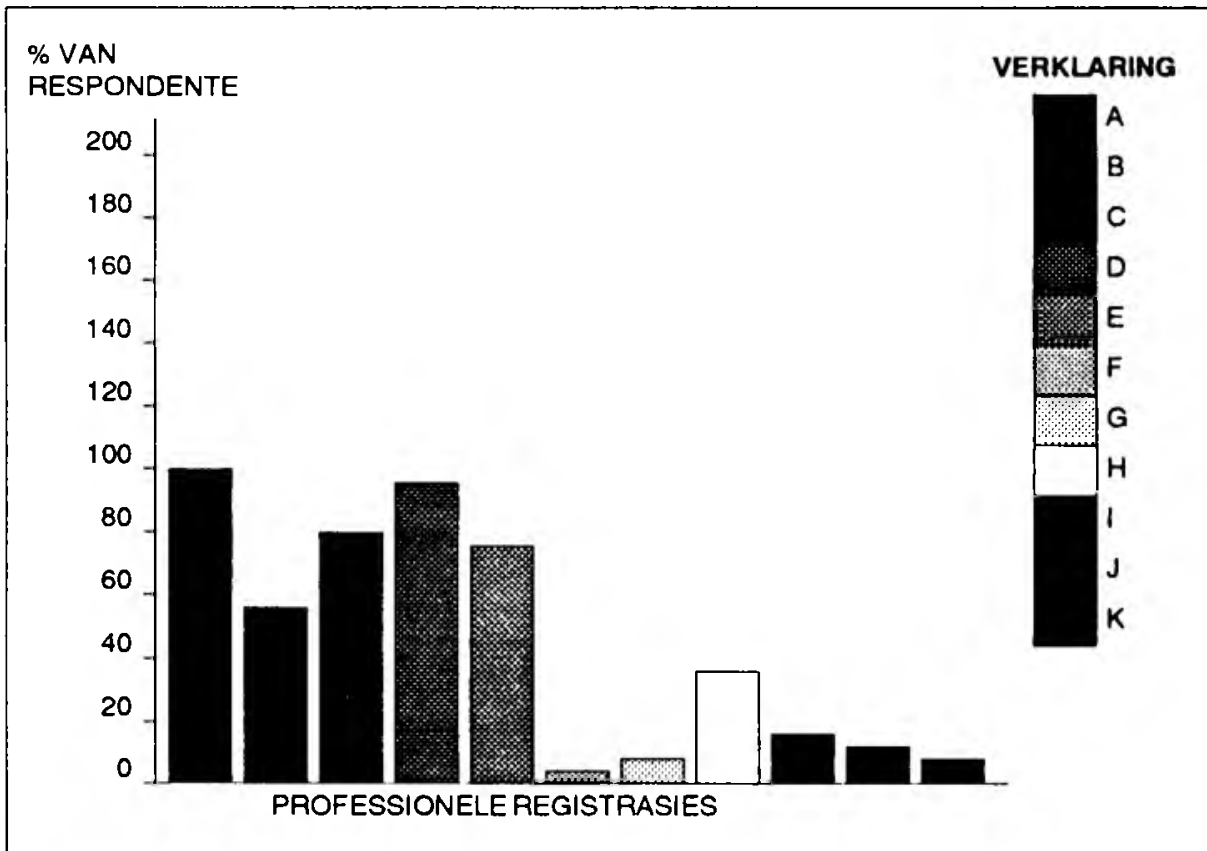

\begin{tabular}{|lcl|}
\hline \multicolumn{2}{|l|}{ VERKLARING: } & \\
A & $:$ & Algemene verpleegkunde \\
B & $\vdots$ & Psigiatrieseverpleegkunde \\
C & $\vdots$ & Gemeenskapsverpleegkunde \\
D & $\vdots$ & Vertoskunde \\
E & $\vdots$ & Verpleegonderwys \\
F & $\vdots$ & Operasiesaaltegniek \\
G & $\vdots$ & Pediatrieseverpleegkunde \\
H & $\vdots$ & Verpleegadministrasie \\
I & $\vdots$ & Kritieke sorg \\
J & $\vdots$ & Geviese verpleegkunde, gesondheidsberaming, behandeling en sorg \\
K & $:$ & Gevorde vertoskunde en neonatale verpleegkunde \\
\hline
\end{tabular}

ekwivalent aan die ontledingseenheid ${ }^{3}$ getoets.

* Die navorser het gedeeltelike anonimiteit verseker in dié $\sin$ dat alhoewel die respondente nic hulle identiteit bekend moes

Honderd agt-en-dertig posvraelyste is gedurende die tweede semester in 1990 uitgestuur waarvan 112 terugontvang is. Aangesien agt vraelyste onvolledig voltooi was, is slegs 104 vraelyste $(75.3 \%)$ vir die opname studie gebruik.

Die vraelyste is van al 16 Departemente van Verpleegkunde aan Suider-Afrikaanse universiteite ontvang. Veertig (62.5\%) van die 64 vrael yste wat aan afdelingshoofde uitgestuur is, $64(86.4 \%)$ vraelyste van die 74 wat aan dosente/vakkundige beamptes/kliniese susters uitgestuur is, is terugontvang.

\section{DATAVERWERKING}

Die SPSS $\mathrm{x} 2$ rekenaarprogram is gebruik om eenrigting-en tweerigting frekwensie verspreidings te bepaal

\section{RESULTATE}

Professionele agtergrond van kliniese evalueerders.

\section{Hoogste akademiese kwalifikasie in Verpleegkunde}

'n Profiel van dic respondente se hoogste akademiese kwalifikasie in Verpleegkunde word in figuur 1 geillustreer.

Uit figuur 1 blyk dit dat $11(10.7 \%)$ respondente slegs 'n Diploma in Verpleegkunde gehad het. In geheel gesien het die meerderheid van respondente oor die volgende akademiese kwalifikasies in Verpleegkunde beskik: Baccalaureus - 21 (20.4\%), 'n Honneurs - 33 (32\%) of 'n Magistergraad 29 (28.2\%). Slegs nege $(8.7 \%)$ respondente het 'n doktorsgraad in Verpleegkunde gehad.

Professionele registrasies in Verpleegkunde

'n Analise van die persentasies soos in figuur 2 aangedui, toon die vol gende met betrekking tot die vicr basiese registrasies:

- alle respondente $(\mathrm{N}=104)$ het 'n professionele registrasie in algemene verpleegkunde;

* slegs $59(56.7 \%)$ was geregistreerde psigiatriese verpleegkundiges;

- $86(82.7 \%)$ was geregistreerde gemeenskapsverpleegkundiges; en

* $100(96.2 \%)$ was as verloskundiges geregistreer.

Wat na-basies registrasies betref het dit geblyk dat:

- nie alle respondente $79(76 \%)$ wat by kliniese evaluering betrokke was, 'n professionele registrasie in verpleeg. onderwys gehad nie; 
Figuur 3

Aantal jare Verpleegpraktyk-ondervinding van respondente $(N=104)$

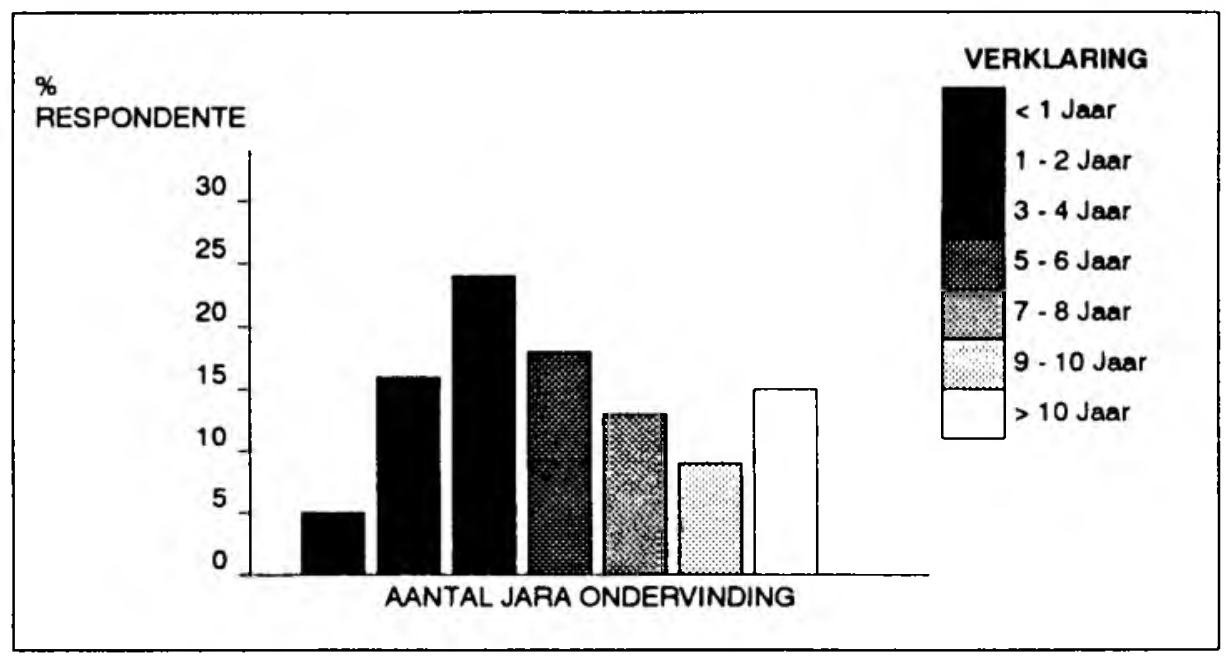

Figuur 4

Aantal jare Verpleegonderwys-ervaring van respondente $(\mathrm{N}=104)$

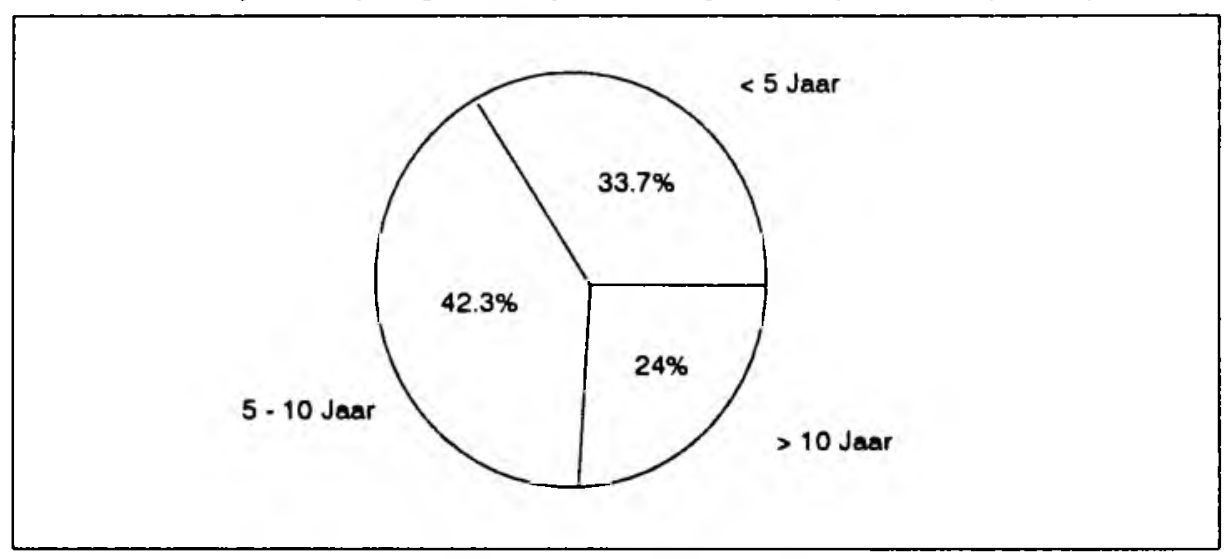

Figuur 5

Respondente se tevredenheid met stendaard van kliniese evaluering $(N=104)$

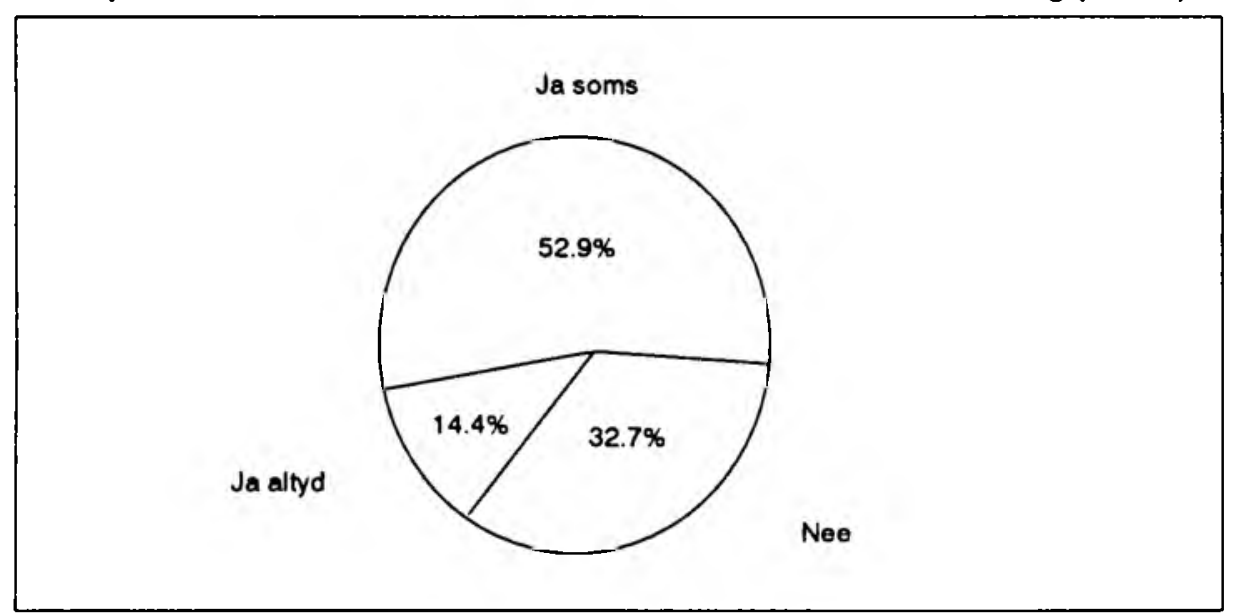

- baie mecr respondente 40 (38.5\%) oor die registrasie verpleegadministrasie beskik, as oor alle kliniese registrasies behalwe die vier basiese kliniese registrasies;

- geen respondent het 'n registrasie in geriatriese of gevorderde pediatriese en nconatale verpleegkunde gehad nie.

Slegs een respondent het ' $n$ registrasie in clk van die volgende professionele registrasie gehad: beplanning, ortopediese verpleegkunde, en gevorderde psigiatricse verpleegkunde. Slegs twee respondente het 'n registrasie in onkologiese verpleegkunde gehad.

\section{Verpleegpraktyk-ondervinding}

Figuur 3 toon dat amper dic helfte 47 (45.1\%) van die respondente minder as vyf jaar verpleegpraktyk-ondervinding gehad het.
Aantal jare verpleegonderwys-ervaring

Volgens figuur 4 is dit duidelik dat 35 (33.7\%) respondente minder as vyf jaar verpleegonderwys-ervaring gehad het, terwyl 25 (24\%) meer as 10 jaar verpleegonderwyservaring gehad het.

Spesiale opleiding in kliniese evaluering

Hierdie vraag is slegs aan die afdelingshoofde gevra $(N=40)$. Slegs $11(27.5 \%)$ afdelingshoofde het aangetoon dat die personeel in hul afdelings spesiale opleiding in kliniese evaluering ontvang.

\section{RESPONDENTE SE MENING MET BETREKKING TO'T KLINIESE EVALUERING}

Dit is interessant om daarop te let dat volgens tabel 1 was $66(63.4 \%$ ) respondente van mening dat kliniese evaluering ' $n$ komplekse taak is. Drie-en-scwentig (70.6\%) respondente was van mening dat kliniese evaluering een van die moeilikste probleme van verpleegonderwys is. Hierdie opvatting stem met dié van verskeic buitelandse verpleegopvoedkundiges ooreen (Woolley, 1977:308; Wood, 1982:11; Pavlish, 1987:338 en Abbot, 1988:219)

Uit ' $n$ analise van die frekwensie en medianc soos in tabeel 1 aangetoon, kan afgelei word dat die meerderheid van die respondente ten spyte daarvan tog kliniese evaluering positief beleef. Dit is ook bemoedigend om daarop te let dat slegs $23(22.3 \%)$ respondente kliniese evaluering as ' $n$ frustrerende taak beleef het en slegs een respondent het dit as 'n hopelose taak gesien.

Nege-en-veertig (48.6\%) respondente was egter van mening dat kliniese evaluering tot 'n groot mate subjektief van aard is. Veertig (38.9\%) respondente was van mening dat dit gevoelens van onsekcrheid by die dosent wek. Hieruit kan afgelei word dat spesiale opleiding moontlik hierdie onsekerheid uit die weg kon ruim en subjektiwiteit in onpartydigheid verander.

\section{TEVREDENIIEID MET STANDAARD VAN KLINIESE EVALUERING}

Uit die grafiese voorstelling in figur 5 is dit duidelik dat $89(85.6 \%)$ van die respondente nie altyd met die standaard van kliniese evaluering in hulle betrokke afdeling van verpleegkunde tevrede was nie. Slegs 15 respondente $(14.4 \%)$ was altyd met die standaard van kliniese evaluering in hulle betrokke afdelings van Verpleegkunde tevrede. 
Flguur 6

Faktore wat volgens respondente standaard van kliniese evaluering belnvloed $(\mathrm{N}=104)^{1}$

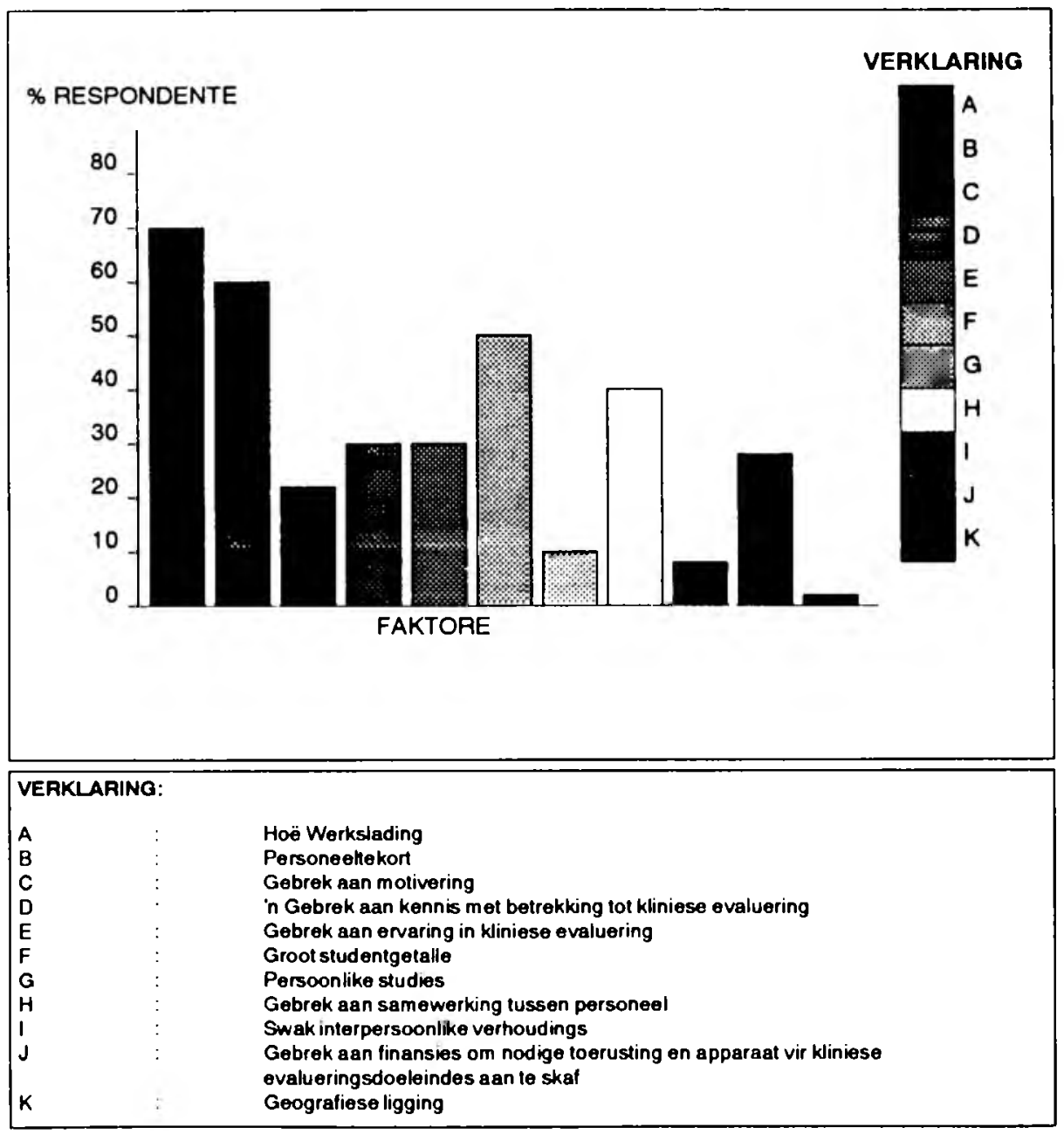

Die afleiding kan dus gemak word dat die standaard van kliniese evaluering in Suider-Afrika kan verbeter.

\section{FAKTORE WAT STANDAARD VAN KLINIESE EVALUERING BEINVLOED}

Soos blyk uit figuur 6 het meer as die helfte van die respondente 'n hoë werkslading $59(70.2 \%)$ personeeltekorl $51(60.7 \%)$ en grool sludentgetalle $44(52.4 \%)$ as faktore geidentifiseer wat die standaard van kliniese evaluering by hul betrokke afdelings van verpleegkunde beinvloed.

Faktore wat in verpleegopvoedkundiges as sulks gesctel is, is ook deur respondente as moontlike redes vir ontevredenheid met die standaard van kliniesc evaluering geïdentifiseer. Byvoorbeeld 'n gebrek aan motivering $20(23.8 \%)$, gebrek aan samewerking $35(41.7 \%)$, gebrek aan kennis met betrekking tot kliniese evaluering $26(31 \%)$, gebrek aan ervaring in kliniese ervaring $26(31 \%)$ en persoonlike studies $9(10.7 \%)$.
Gesien in die lig van dic huidige finansiële klimaat (verminderde staatsubsidiering aan universiteite) is dit verbasend dat slegs 24 (28.6\%) respondente 'n gebrek aan finansies as 'n faktor vir ontevredenheid met die standaard van kliniese evaluering geidentifiseer het.

\section{PROBLEME MEII KLINIESE EVALUERING}

Sestien (15.4\%) respondente het geen probleme met kliniese evaluering ondervind nie.

Slegs ses $(5.8 \%)$ het altyd probleme ondervind en $82(78.8 \%$ ) respondente het mettye probleme ondervind.

Diegene wat wel probleme ondervind, het $\mathbf{4 0 0}$ probleme aangemeld. Die navorser het die probleme en voorgestelde oplossings in 10 katcgoricë geklassifiseer (kyk tabel 2).

Dit is interessint om daarop te let dat probleme wat verband hou met die personeel van die opleidingskool en spesifick die evaluecrder self, die grootste katcgorieè was. 'n Kwart van die probleme 102(25.5\%) het met die personeel van die opleidingskool verband gehou en 95
(23.8\%) met die evalueerder se bevoegheid en ingesteldheid teenoor kliniese evaluering.

Twee ander kategoriek waaronder ook heclwat probleme geklassifiseer is, was studentgetalle en die geregistreerde verpleegkundige in dic kliniese praktyk. Slegs 20 probleme $(5.0 \%)$ het met gebrekkige evalueringsmetodes en/of -tegnieke verband gehou

Volgens Tabel 2 is dit ook praktiese oplossings vir sommige probleme voorgestel. 'n Paar voorgestelde oplossings was egter onnadenkend. (Byvoorbeeld dat minder opleidingsposte gevul moet word, terwyl daar reeds 'n tekort aan verpleegkundiges in Suider-Afrika is). Dit is interessant om daarop te let dat van die oplossings met kliniese onderrig verband hou. Dit beklemtoon weereens die feit dat kliniese evaluering ' $n$ onlosmaklike komponent van die onderrig-lecrproses is.

Uit die oplossings wat vir kategorie drie (die evalueerder) voorgestel word, word die kem van die probleem, naamlik onbevoegde evalueerders wat reeds aangestel is, nie aangespreek nie.

Volgens die oplossings wat vir kategorie ses (personeel van opleidingskool) voorgestel is wil dit blyk asof die kern van die probleem deels swak personeelbestuur is en nie net ' $n$ tekort aan personeel nie. Die tipe probleme wat in kategorie 10 (geregistreerde verpleegkundige in die kliniese praklyk) geklassifiseer is, is ook baie goed in die buitelandse literatuur beskryf (Schweer en Gebbie, 1976:183; Kehoe \& Harker, 1979:47-50, 87-80; Robertson, 1980:30-37; Ficld et al., 1984:19 en Infante, 1986:94-96)

\section{AANBEVELINGS}

Volgens die empiriese bevindings het dit geblyk dat dic Suid-Afrikanse verpleegopvocdkundige se bekwaamheid, wat kliniese evaluering betref, nie volkome op standaard is nie.

In die lig hiervan wil die navorser die volgende aanbevelings maak:

* Personeclaanstellings moet met groter omsigtigheid gedoen word. 'n Suksesvolle evalueerder moet in die lig van die eise wat tydens kliniese evaluering aan hom/haar gestel word aan ten minste die volgende vereistes voldoen, naamlik beskik oor: - ' $n$ baccalaureus-graad in Verplecgkunde; - dic vier basiese registrasies in Verpleegkunde (of dan ten minste dric registrasics);

- vyfjaar praktykervaring in kliniese verpleegkunde; en

- 'n kwalifikasies in verpleegonderwys

1 Nege-en-lagog respondente moes an annleiding van hul respons op die vrasg hierdie vrasg hesnnwoord.

Sleps 84 hel dit heannwoord. 
TABEL 1

OPVATTING VAN RESPONDENTE MET BETREKKING TOT KLINIESE EVALUERING

\begin{tabular}{|c|c|c|c|c|c|c|c|c|}
\hline \multirow[t]{2}{*}{ STELLING } & \multicolumn{8}{|c|}{ OPVATTING } \\
\hline & & $\begin{array}{c}\text { Stem beslis } \\
\text { eaem } \\
1\end{array}$ & $\begin{array}{c}\text { Stem seam } \\
2\end{array}$ & $\begin{array}{c}\text { Staen neutraal } \\
3\end{array}$ & $\begin{array}{c}\text { Stem nie saam } \\
\text { nie } \\
4\end{array}$ & $\begin{array}{c}\text { Stem besile nie } \\
\text { soem nie } \\
5\end{array}$ & & \\
\hline Klinlese evaluering: & $\mathbf{N}$ & $f(x)$ & $f(\boldsymbol{x})$ & $f\left(x_{0}\right)$ & $f(*)$ & $f(\boldsymbol{x})$ & $M_{*}^{*}$ & Mo* \\
\hline $\begin{array}{l}\text { is vir die dosent 'n komplekse } \\
\text { (ingewikkelde) taak }\end{array}$ & 104 & $30(28.8)$ & $36(34.6)$ & $12(11.5)$ & $21(20.2)$ & $5(4.8)$ & 2 & 2 \\
\hline is vir die dosent 'n opwindende ervaring & 104 & $33(31.7)$ & $39(37.7)$ & $18(17.3)$ & $11(10.6)$ & $3(2.9)$ & 2 & 2 \\
\hline $\begin{array}{l}\text { verbeter die interpersoonlike verhouding } \\
\text { tussen dosent en student }\end{array}$ & 104 & $52(50)$ & $36(34.6)$ & $8(7.7)$ & $5(4.8)$ & $3(2.9)$ & 1 & 15 \\
\hline is tot 'n groot mate subjektief van aard & 101 & $6(6.0)$ & $43(43)$ & $13(13)$ & $31(31)$ & $7(7)$ & 2 & 3 \\
\hline $\begin{array}{l}\text { voorsien aan ' } n \text { dosent } \\
\text { werksbevrediging }\end{array}$ & 104 & $22(21.2)$ & $54(51.9)$ & $14(13.5)$ & $11(10.6)$ & $3(2.9)$ & 2 & 2 \\
\hline $\begin{array}{l}\text { is een van die moeilikste probleme } \\
\text { waarmee verpleegonderwys vandag te } \\
\text { doen het }\end{array}$ & 103 & $39(37.9)$ & $34(33)$ & $12(11.7)$ & $17(16.5)$ & $1(1.0)$ & 1 & 2 \\
\hline $\begin{array}{l}\text { bied 'n uitdaging aan die dosent se } \\
\text { kreatiwiteit }\end{array}$ & 104 & $57(54.8)$ & $35(33.7)$ & $7(6.7)$ & $3(2.9)$ & $2(1.9)$ & 1 & 1 \\
\hline $\begin{array}{l}\text { wek gevoelens van onsekerheid by } \\
\text { dosent }\end{array}$ & 103 & $8(7.8)$ & $32(31.1)$ & $18(17.5)$ & $34(33)$ & $11(10.7)$ & 4 & 3 \\
\hline is 'n ontwikkelingsproses vir die dosent & 103 & $45(43.7)$ & $53(51.5)$ & $1(1.0)$ & $3(2.9)$ & $1(1.0)$ & 2 & 2 \\
\hline is vir die dosent 'n frustrerende taak & 103 & $7(6.8)$ & $16(15.5)$ & $27(26.2)$ & $33(32)$ & $20(19.4)$ & 4 & 4 \\
\hline is ' $n$ hopelose taak & 103 & - & $1(1.0)$ & $4(3.9)$ & $30(29.1)$ & $68(66)$ & 5 & 5 \\
\hline is deel van professionele sosialisering & 100 & $47(47)$ & 45(45) & $3(3)$ & $3(3)$ & $2(2)$ & 1 & 2 \\
\hline
\end{tabular}

* Die waarde van die Me of Mo stem met die numeriese waarde van die responskategorieē ooreen.

TABEL 2

PROBLEME MET KLINIESE EVALUEAING

\begin{tabular}{|c|c|c|c|}
\hline & $\begin{array}{l}\text { KATEGORIË̈ VAN } \\
\text { PROBLEME }\end{array}$ & $\begin{array}{l}\text { KORT OMSKRYWING VAN AARD } \\
\text { VAN PROBLEME }\end{array}$ & $\begin{array}{l}\text { KORT OMSKRYWING VAN VOORGESTELDE } \\
\text { OPLOSSING }\end{array}$ \\
\hline 1. & Studentgetalle & $\begin{array}{l}\text { Te veel studente in verhouding tot aantal } \\
\text { evalueerders. }\end{array}$ & Keur studente voor toelating; vul minder opleidingsposte. \\
\hline 2. & Ligging van universiteit & $\begin{array}{l}\text { Vervoerprobleme; beperkte kontak met } \\
\text { universiteite; ver gelee vanaf } \\
\text { gesondheidsorginstensies waar studente hulle } \\
\text { praktika voltooi. }\end{array}$ & $\begin{array}{l}\text { Studente moet onderrig in 'n lokaal naby die } \\
\text { gesondheidsorginstansie ontvang; beter beplanning van lesing-en } \\
\text { werkstye. Interdepartementele skakeling met betrekking tot } \\
\text { kliniese evaluering; forum vir kliniese evaluering; nuusbrief en } \\
\text { gereelde werkswinkels. }\end{array}$ \\
\hline & Evalueerder & $\begin{array}{l}\text { Gebrek aan motivering, objektiwiteit, kennis, } \\
\text { ondervinding en vaardigheid in psigomotoriese } \\
\text { vaardighede. Onsekerheid met betrekking tot } \\
\text { standaard wat tydens kliniese evaluering } \\
\text { gehandhaaf moet word. Weerstand teen } \\
\text { verandering. Geen eenvormigheid. Het geen } \\
\text { oriëntering ten opsigte van kliniese evaluering } \\
\text { ontvang nie. }\end{array}$ & $\begin{array}{l}\text { Noukeurige keuring van personeel voor aanstelling; motiveer } \\
\text { evalueerder; vereis meer kliniese praktykondervinding. } \\
\text { Spesialisasie in vakgebied moet aangemoedig word. }\end{array}$ \\
\hline
\end{tabular}


Tabol 2 Probleme met Kliniese Evaluering (Vervolg ...)

\begin{tabular}{|c|c|c|c|}
\hline \multicolumn{2}{|c|}{$\begin{array}{l}\text { KATEGORIË̈ VAN } \\
\text { PROBLEME }\end{array}$} & $\begin{array}{l}\text { KORT OMSKRYWING VAN AARD } \\
\text { VAN PROBLEME }\end{array}$ & $\begin{array}{l}\text { KORT OMSKRYWING VAN VOORGESTELDE } \\
\text { OPLOSSING }\end{array}$ \\
\hline 4. & $\begin{array}{l}\text { Evalueringsmetodes } \\
\text { en -tegnieke }\end{array}$ & $\begin{array}{l}\text { Gebrek an geldige on betroubare } \\
\text { evalueringsinstrumente. }\end{array}$ & $\begin{array}{l}\text { Evalueringsinstrumente moet kognitiewe, affekliewe en } \\
\text { psigo-motoriese domein gesamentlik evalueer. } \\
\text { Evalueringsinstrumente moetmeer gereeld hersien word. Simbole } \\
\text { moet in die plek van persentasies vir puntetoekenning gebruik } \\
\text { word. Evalueringsinstrumente moet deur al die personeel } \\
\text { gesamentlik opgestel word. } \\
\text { Graderingskale moet verbeler word. (Kriteriumgerigte skale). } \\
\text { Korreleer metodes en tegnieke volgens kliniese doelwitte. Gebruik } \\
\text { meer gevallestudies. Toets instrumente se geldigheid en } \\
\text { betroubaarheid. Onderneem begrondingstudies metbetrekking tot } \\
\text { basiese konsepte wat in verpleegkunde gebruik word. }\end{array}$ \\
\hline 5. & Kliniese evaluering & $\begin{array}{l}\text { Prosedure georienteerd; evalueer slegs in } \\
\text { gesimuleerde opset; word nie as in } \\
\text { vormingsgeleentheid vir die student benut nie; } \\
\text { geen plan of skedule word gebruik nie; te min tyd } \\
\text { vir kliniese evaluering; Hawthorn-effek; } \\
\text { affektiewe domein word nie geëvalueer nie. }\end{array}$ & $\begin{array}{l}\text { Normgroepgerigte evaluering; beter beplanning; } \\
\text { bemeesteringsleer; terugvoer moet aan student verskaf word - } \\
\text { vormende evaluering; opsommende evaluering - slegs kritieke } \\
\text { aspekte; Departemente moet meer outonomie (onafhanklikheid } \\
\text { van universiteite) kry; kliniese onderrig moet probleem-en pasiënt } \\
\text { georiënteerd wees; daar moet meer klem geplaes word op die } \\
\text { kliniese prosedure as 'n middel tot seltstandige ontwikkeling van } \\
\text { die pasiënt en sy gesin; klemverskuiwing van kuratief na } \\
\text { voorkomend en rehabilitatief. }\end{array}$ \\
\hline 6. & $\begin{array}{l}\text { Personeel van } \\
\text { opleidingskool }\end{array}$ & $\begin{array}{l}\text { Personeeltekort; hoë werkslading; swak } \\
\text { personeelbestuur. }\end{array}$ & $\begin{array}{l}\text { Gesondheidsinstansies moet poste skep vir kliniese evalueerders; } \\
\text { studente moet aan kliniese evalue erders toegewys word sodat } \\
\text { werksverdeling regverdig is; meer personeel moet aangestel word; } \\
\text { beter verspreiding van werkslading; gebruik na-basiese studente } \\
\text { of finale jaar studente om met kliniese evaluering te help. }\end{array}$ \\
\hline 7. & Studente & $\begin{array}{l}\text { Hoë spanningvlakke; gebrek aan voldoende } \\
\text { leergeleenthede; nie aktief by kliniese evaluering } \\
\text { betrokke nie; gebrek aan motivering; word as } \\
\text { werkkragte in gesondheidsorginstansies gebruik; } \\
\text { nie bekend mel inhoud van kliniese } \\
\text { evalueringsinstrumente nie. }\end{array}$ & $\begin{array}{l}\text { Onderrig studente slegs in basiese beginsels van kliniese praktyk; } \\
\text { studentselfevaluering; beskikbare fasiliteite en } \\
\text { gesondheidsorginstansies moet optimaal benut word; studente } \\
\text { moet nie deel van werkkrag wees nie (botallig); voldoende } \\
\text { geleentheid kry om vaardig teraak; gemengde hospitale-toelating } \\
\text { van anderskleuriges; meer interaksie tussen dosent en student; } \\
\text { deeglike oriëntering van studente ten opsigte van kliniese } \\
\text { evaluering. }\end{array}$ \\
\hline 8. & Finansies & $\begin{array}{l}\text { Gebrek aan finansies; gebrek aen toerusting en } \\
\text { apparaat vir simuleringslaboratoria. }\end{array}$ & 'Apartheid' moet afgesk af word. \\
\hline 9. & $\begin{array}{l}\text { 'Apartheid' moet } \\
\text { afgeskaf word. }\end{array}$ & $\begin{array}{l}\text { Werklike kliniese praktyk werksarea te besig, kan } \\
\text { nie kliniese evaluering toepas nie; oorbenutting } \\
\text { van pasiente vir kliniese evaluering. }\end{array}$ & Simulering. \\
\hline 10. & $\begin{array}{l}\text { Geregistreerde } \\
\text { verpleegkundige in } \\
\text { Kliniese Praktyk }\end{array}$ & $\begin{array}{l}\text { Gebrek aan samewerking mel opleidingskool; } \\
\text { geen ondersteuning van studente; aanvaar nie } \\
\text { verantwoordelikheid vir kliniese evaluering nie; } \\
\text { funksionele werkstoewysing; klem op } \\
\text { psigomotoriese domein; voorsien nie aan } \\
\text { studente die geleentheid om } \\
\text { bestuursvaardigheid in te oefen nie; swak } \\
\text { rolmodel; negatiewe houding jeens kliniese } \\
\text { evaluering. }\end{array}$ & $\begin{array}{l}\text { Verpleegopvoedkundige moet praktykbegeleiding doen; } \\
\text { geregistreerde verpleegkundige in die praktyk moet gewys word op } \\
\text { haar invloed as rolmodel, beter skakeling tussen opleidingskool en } \\
\text { gesondheidsorginstansie moet aangemoedig word. }\end{array}$ \\
\hline
\end{tabular}

- Bestaande personeel en alle nuwe aanstellings mœt' $n$ opknappingskursus in kliniese evaluering deurloop.

- Verpleegopleidingskole wat in ' $n$ bepaalde geografiese area geleë is, kan 'n kliniesc evalueringswerksgroep stig. Deelname aan dic bespreking en aktewitcite van so 'n werksgroep kan die ideale leergeleentheid vir jong, onervare evalueerders bied. Kliniese evalueringsinstrumente kan gesamentlik opgestel word; probleme mel kliniese evaluering kan aan die groep voorgelê word vir moontlike aanbevelings; nuwe ontwikkeling en navoringsbevindinge kan deurlopend aan die lede voorgchou word.
- Die inhoud van bestaande Verpleegonderwyskurrikula moet krities beoordeel word om seker tc maak dat kliniese evaluering as komponent van die onderrig-leerproses deeglik gedek word.

- Baie universiteite vereis nou van hul personcel om hulself beter te bekwaam op nagraadse vlak. Meer navorsing en publikasies word as 'n voorvereiste gestel. Om aan hierdic eise te voldoen, nog steeds klinies bevoegd te bly en effektiewe kliniese onderrig en cvaluering te verseker, is dit noodsaaklik dat ander persone (byvoorbeeld dic geregistreerde verpleegkundige in die kliniesc praktyk) ook doelbewus by kliniese evalucring betrek word.
Dit dien geen doel om nog steeds die geykte standpunt in te neem dat kliniese evaluering buitendien deel van die kliniese verpleegpraktisyn se taak is nie en intussen realiseer kliniese evaluering in die kliniese praktyk nie na wense nie.

Aangesien studente buitendien as werkkragte diens doen, is die navorser van mening dat gesondheidsorginstansies ook 'n verpligting het om ' $n$ bydrae te lewer tot hoevlakberocpsvoorbereiding en indirek 'n hoc standaard van verplecgsorg.

Gesondheidsorginstansies moet spesiale poste skep vir kliniese evalueerders of sekere personeel vir die doel afsonder. Hierdie persone 
moet spesiaal déur die betrokke opleidingskool vir hierdie taak opgelei word en ook aktief tydens die beraming en beplanning van kliniese evaluering betrek word.

Die navorser voorsien dat hicrdie personeel dan 'n groter bewuswording sal toon ten opsigte van hulle verantwoordelikheid as 'n professionele rolmodel en hul taak as evalueerder in 'n nuwe lig sal sien.

Soos vroeër genoem word die tweede hoofdoelstelling, naamlik 'n model vir kliniese evaluering, as die hoofaanbevelings in 'n opvolgartikel bespreek.

\section{SLOTSOM}

Die navorser wil aanbeveel dat addisionele navorsing met betrekking tot kliniese evaluering voorrang geniet. Kliniese navorsing is belangrik mar in die lig van gesondheidsorgkoste wat dié hoogtes inskiet, ' $n$ afname in die voorsiening van verpleegkundiges, 'n toename in die koste van tersiêre opleiding en ' $n$ afname in die baccalaureur-verpleeginskrywings moet die professie bewys dat ' $n$ baccalaureus. verpleegopleiding ' $n$ klinies bevoegde praktisyn lewer wat aan die eise van' $n$ professionele verpleegkundige voldoen.

\section{BIBLIOGRAFIE}

ABBATT, F. AND MCMAHON, R. 1985 Teaching health-care workers. A practical guide. London: MacMillan.

GUILBERT, J.J. 1981. Educational handbook for health personnel. New York: Springer Publishing Company.

KOLB, S.E. AND SHUGART, E.B. 1984 Evaluation: Is simulation the answer?
Journal of Nursing Education, Vol. 23, no. 2, February, pp. 84-86.

LENBURG, C.B. 1978. Nursing. The New York regents external degrees-assessment model. In Evaluating clinical competence in the health professions. Comp. by M.K. Morgan and D.M. Irby. Saint Louis: The C.V. Mosby Company, pp. 259-270.

LITWACK, L. SAKATA, R. AND WYKLE, M. 1972. Counseling, Evaluation and Student Development in Nursing Education. Philadelphia: W.B. Saunders Company.

LOUSTAU, A., LENTZ, M., LEE, K., MCKENNA, M., HIRAKO, S., WALKER, W.F. AND GOLDSMITH, J.W. 1980. Evaluating students' clinical performance: Using videotape to establish rater reliability. Journal of Nursing Education, Vol. 19, no. 7, September, pp. 10-17.

LYNCH, E.A. 1974. The "What", "Why" and "When" of evaluation. In Faculty Curriculum Development. Part II. New York: National League for Nursing, pp. 1-7. (Pub. no. 15-1530).

MORGAN, M.K. \& IRBY, D.M. 1978 Evaluating clinical competence in health professions. Saint Louis: The C.V. Mosby Company.

MULDER, M. 1990. 'n Ondersoek na kliniese evaluering in Verpleegkunde aan Suider-Afrikaanse universiteite. Bloemfontein: Universiteit van die Oranje-Vryslaat.

SACHS, L.P. 1980. Performance evaluation. In Measurement and evaluation in nursing education. New York: National League for Nursing, pp. 61-64 (Pub.no. 17-1807).
SOMMERFIELD, D.P. AND ACCOLA, K.M. 1978. Evaluating students' performance. Nursing Outlook. Vol. 26, no. 7, July, pp. 432-436.

SWEENEY, M.A., HEDSTROM, B. AND O'MALLEY, M. 1982. Process evaluation: A second look at psychomotor skills. Journal of Nursing Education, vol. 21, no. 2, pp. 4-17.

WOOD, V. 1982. Evaluation of student nurse clinical performance - a continuing problem. International Nursing Review, vol .29, no. 1, pp. 11-18.

WOOLLEY, A.S. 1977. The long and tortured history of clinical evaluation. Nursing Outlook. vol. 25, no. 5, May, pp. 308-315.

\section{Erkennings}

Die navorser wil erkenning verleen aan Elzabé Gleeson vir die tik van die manuskrip en Mej. M.V. Vermaak vir die taalkundige versorging.

Die navorsing, onder leiding van Professor M.J. Viljoen, is as primêre verciste vir graad D.Soc.Sc. voltooi.

Dr Magda Mulder GV. VV. GVV en PV M.Soc.Sc.(Kriticke sorg en verpleegondernys) D.Soc.Sc. (Verpleegkunde) Universiceit van Oranje-Vrystaat Departement van Verpleegkunde Bloemifontein

Professor Marlene Viljoen M.Cur (Intensiewe Verpleegkunde) M.Cur (Verpleegadministrasie) Universiteit van Oranje-Vnystaat Bloemfontein 